\section{SCIENCE IN WESTERN SZECHUAN}

I. PHYSICO-CHEMICAL SCIENCES AND TECHNOLOGY

\section{BY DR. JOSEPH NEEDHAM, F.R.S.} British Scientific Mission in China

$I^{N}$ the foregoing articles of this series* the attempt has been made to report to Western scientific men something of the remarkable efforts of their Chinese colleagues in a pre-industrial hinterland lacking all modern resources. The attempt is here continued with respect to the western parts of the province of Szechuan, lying between the Tibetan borderlands to the east and the Yangtze valley in Hubeh to the west.

The principal city of western Szechuan is Chengtu. When Chinese jokingly discuss which city of Free China represents the lost cities of eastern China, Chengtu is always analogized with Peiping; and it does indeed have the air of ancient city culture. It covers a very large area, much of the city wall still stands, and it is rich in old bookshops. It might remind the English visitor of York (for some of the Buddhist abbeys are reminiscent of any cathedral close) if it were not so flat, with willow-fringed canals not unlike those of the Cambridge fens. Chengtu has for many years been the home of the ('missionary') West China Union (Huahsi) University, the buildings of which, erected in semi-Chinese style on an admirable campus, are now by far the best of any university in Free China. This University has very hospitably accepted no fewer than four other universities (all originally 'missionary', now known as 'private', as opposed to State, or national, universities) as ovacuees, namely, Chilu University from Shantung, Yenching University from Peiping, Nanking University from Nanking, and Ginling Women's College (the Chinese counterpart of Girton College, Cambridge), also from Nanking. The total number of students is to-day somewhat more than 3,000, of which two thirds are men and one third women. In general, it may be said that these private universities concentrate mainly on undergraduate teaching and less on the higher walks of research than some of the other Chinese universities, but the importance of a great centre of student life under comparatively good conditions of existence in these days should not be underestimated. Among the presidents of these institutions are some internationally known scholars, such as Dr. Mei Yi-Bao of Yenching, the translator of the philosopher Mo-Tze, and Dr. Wu Yi-Fang of Ginling College.

A good deal of fusion of the scientific departments of these Universities has taken place in practice, though theoretically they are still distinct. In general, research interest is concentrated on practical problems of importance to the community. Thus the chemists of Huahsi University (Profs. Roy Spooner and Chang Chuan) direct investigations on the indigo and natural dyestuff industry of the province, on gelatin emulsions with reference to the production of X-ray plates, on the properties of Chinese soapnut saponins, on electroplating, and on tanning, for which there is an elaborate experimental plant established on the campus. Here all kinds of improvisations, under Dr. Chang's initiative, have had to be thought of ; all the machinery is made of local woods, and when emery wheels cannot be had, one imitates them by setting broken glass in a medium of tung

-See Nature, July 3, p. 9, July 10, p 36, and July 17, p 64, 1943. oil. In Chilu University, Prof. Hsieh Yu is interested primarily in the active principles of indigenous drugs, especially anti-malarials. In Ginling University, Prof. Tai An-Bang, a colloid chemist, supervises work on soy-bean globulins (important for the production of 'casein' glue), copper insecticides, and tung oil polymerization. It will be seen that here, as much as, if not more than, in any other Chinese universities visited, research on immediate war problems is going on, just as in Britain. But the burden of teaching weighs heavily on the staffs of these Universities, and until it is lifted attainment of a high level of research can scarcely be expected. One of the most outstanding scientific men at Chengtu is probably Dr. Li Fang-Hsun, the physical chemist of Ginling University, whose work on ionic entropies, ionic volumes, hydration, etc., is widely known. So also is the work of Dr. Li Hen, the mathematician and astronomer of Huahsi University, a member of the National Academy.

One of Dr. Li Fang-Hsun's colleagues, Dean Wei Shioh-Rjeng, an extremely capable organizer, has collaborated with the progressive director of education of Szechuan province, Commissioner Kuo YoShou, in setting up a factory for producing school and simple laboratory apparatus. This goes out to eleven other provinces as well, and includes good chemical balances weighing to $1 / 5 \mathrm{mgm}$. and all imaginable physical and chemical apparatus and chemical reagents. The plant includes a glass factory. To illustrate the primitive conditions which must often be overcome, it was remarkable to see a dynamo for providing a low-voltage electric current for electroplating operated by hand, as no main current is available in this region outside the eity. Mention may also be made at this point of a Popular Science Hall, planned along the lines of the Science Museum at South Kensington, but only just installed in some buildings of an old temple. It was pleasant to see in the garden stone models of the principal figures in solid geometry, with inscriptions in Chinese assiduously studied in the shade of the trees by small Chinese boy scouts.

The best applied physics and chemistry in Chengtu is probably going on in the experimental establishments of the Chinese Air Force Research Bureau, directed by Colonel Wang Tzu, but details cannot be given here for security reasons.

Turning now to a few words on the technology of the region, which is exceptionally interesting, China has in the Tzuliuching (lit. "Self-flowing Well") area an inspiration to her modern industrial chemists. For centuries back, so far that the memory of man runneth not to the contrary, there have been brine wells in this area, sunk by local methods using bamboo rope-suspended drills working for perhaps twenty years to complete one boring, and producing several sorts of brine, black, white and yellow. These brines are of different composition, and from them, by modern methods, partly in private factories, and partly in plants under the National Resources Commission, numerous important salts are separated (for example, salts of barium, boron, magnesium, lithium, strontium, bromine, etc.). Not many miles away, at Fivebridges, the Huanghai Industrial Research Institute (a privately supported organization on the same lines as the Mellon Institute at Pittsburgh, but in an entirely rural setting, ably directed by Dr. Sun Shioh-Wo and Dr. Chang Chien-Long) analyses these brines and works out new methods of separating their constituents. 
The brine rcgion is indeed nothing more nor less than an industrial area in the midst of a vast preindustrial country and civilization. Needless it would be to point out the fundamental importance of such a source of salt in Central Asia so far from the seacoast. The technique remains primitive to this day; a bamboo cable drops down the boring for two or three thousand feet and is wound up on a huge horizontal drum driven round by oxen. Steam and electric winding-gear is now, however, being introduced. But yet another circumstance is remarkable, namely, that the brine is associated with enormous amounts of natural gas, and one may see vast halls with hundreds of pans of evaporating brine each heated by a large burner connected with a boring. Still more extraordinary is the use of bamboo piping for conveying the brine from the wells to the factories over miles and miles of country. These bamboos are bound round outside with bamboo strips and cernented together with tung oil and lime; they stand a pressure of $80 \mathrm{lb}$. per sq. in. Unfortunately, bamboo will not do for water-supply in towns, as it is rotted by fresh water.

Such is ancient chemical technology in west China ; the new has other features we must admire. Under the National Resources Commission, industrial plants have sprung up everywhere in Szechuan. In the sugar-producing area around Inwardstream (I garbletranslate the place-names as usual), there are large works producing power alcohol from molasses for motor-vehicles; that directed by Dr. Chang Chi-Hsi is an example. Urea from human waste serves systematically here as nitrogen-source for culturing the yeast. Near Fivebridges there is an admirablo low-temperature carbonization plant (the coal supply is difficult, seams being usually only $2 \mathrm{ft}$. thick over a wide area) directed by Dr. Huang Rjeng-Chi, and a wood dry-distillation plant directed by Dr. Gao ChangKung. Now the characteristic of all these plants is that they are usually built and operated by men of general chemical engineering training but without special experience, who went, as it were, into the wilderness and 'created' (the French idiom alone expresses it) the beginnings of industry, under the urge of war but with an eyo to the peace. From the high lecture-hall of Wuhan University at Chiating, a lovely town at the junction of two great rivers tributary to the Yangtze, one sees in the far distance two things-a statue of Buddha $360 \mathrm{ft}$. high carved in the cliff, and on the other side a factory chimney. The social gospel of Confucian this-worldliness is conquering at last.

Wuhan University at Chiating, presided over by Dr. Wang Hsing-IKung, himself a chemical engineer, is housed partly in a beautiful Confucian temple, with its library occupying the shrine of the sage itself; but the physico-chemical departments are located in an old family temple with a charming loggia on tho top of the city wall overlooking the river with the great Buddhist place of pilgrimage, Mount Omei, in the distance. Here Dr. Hu Chien-Shnn (one of Prof. P. M. S. Blackett's most eminent collaborators) works and teaches; he has just completed a book in Chinese on cosmic rays. Head of the Chemistry Department is Dr. Wu Pao-Liang, the physical chemist, who has recently published an interesting work on omni-range electrical forces and static nuclei. He emphasized the isolation of scientific men in this remote spot in his need for up-to-date data on nuclear masses. The theoretical physicist is Dr. Chiang Rjeng-Shou (a former collaborator of Prof. E. N. da C. Andrade); he is directing the work of Liu Li-Ben on copper oxide rectifiers and that of Lo Wei-Kuang on the effect of temperature on elasticity in metals. In chemistry, Dr. Yeh Chiao investigates the active principles of indigenous drugs. While at Wuhan I had the pleasure of seeing a microfilm-reading machine arrive from International Cultural Service at Chungking (this deserves an article to itself) together with many microfilms. We got the machine working and the first films at which we looked were Science and Journal of Nutrition up to February 1943. The delight of these isolated men may easily be imagined. But nearly all the material so far coming in this way is from the American side, and on the British side we are only just belatedly beginning.

There is no doubt that at Wuhan University the scientific level is very high, comparing favourably even with the National Southwest Associated Universities at Kunming. Chiating, however, contains other institutions of some interest. We may mention the Polytechnic College, where courses are given in all branches of chemistry and engineering pertaining to light industry ; for example, in agriculture, paper. making, textiles, leather and sericulture. The lonely location of all this region may be visualized by the remark made by the engineer of one of the National Resources Commission power stations, who said, as wo stood at the door looking towards tho Tibetan border mountains, "Remember that this is the last. power plant until you come northwest to the Soviet Union across Central Asia six degrees of longitude west and three degrees north !"

Another academic institution of the first rank is Tongchi University, situated in the very small town of Appletree Rapids a hundred miles or so down the Yangtze. It was originally the German-Chinese University, and the atmosphere is still mainly German, though of course anti-Nazi. Its president is Dr. Ting Wen-Yuan, a younger brother of the famous geologist V. K. Ting. Itg headquarters are in an extremely beautiful temple beside the river dedicated to Ta Yü, the legendary engineer who first established China's irrigation systems. Under the carved and gilded beams and roofs portraying the life of this great organizer and technologist, the students gather for special lectures or pass to and from their classrooms. I was privileged to be there on the annual day dedicated to 'Ta Yü's memory, and to address the students, after the usual ceremonies and a speech on the work of engineers in China by Dr. Ni Chao, Here at Tongchi the departments of physics and chemistry live but a struggling life, for as at Wuhan, their apparatus was much damaged by bombing and transportation from the east, but the engineering departments are flourishing. Tho University has its own power plant, and the students spend much time in assembling und erecting a large amount of plant brought up-river. There is United Nations collaboration here, for the professor of steel construction is a Pole. Particularly striking is the Department of Geodetics, Surveying and Cartography under the able Dr. Yeh Shwi-An, with excellent equipment; this has almust a monopoly of the production of Chinese surveyors and mapmakers.

The definitely religious veneration paid to the great irrigation engineer, Ta Yü, is of much interest. Some distance to the north-west of Chengtu there is a town callod Kuanhsien, where may be seen what must be one of the most remarkable irrigation works of the world. A great river, the Min Chiang, issuing from the mountainous country of the Tibetan borderland, 
is there diverted at certain seasons of the year by movable dams and spillways into an enormous cutting through a hillside, forming thereby an artificial river which fertilizes 500,000 acres of first-class agricultural land by means of $1,200 \mathrm{~km}$. of irrigation channels. But the striking feature of the work is that it was begun in 250 B.C. by $\mathrm{Li}$ Bing, then governor of this province, and has been kept up ever since. Moreover, the Chinese were not content to regard such works from a purely utilitarian point of view. With their characteristic ability to raise the highest secular to the level of the numinous, they built upon the outermost spur of the hill through which the river cuts, a magnificent temple to Li Bing, and farther up, in a scarcely less beautiful situation, a wooded hillside next the river, another one to his son, also an irrigation engineer, Li Erh Lang. Note the contrast : incense sticks glow in the front of Li Bing's temple, but in its second court are numerous models of the improvements it is intended to make to the irrigation scheme. So also in Li Erh Lang's temple, the engineers have their living quarters, and the shrine and courtyard of Ta Yü is the Water Conservancy Office. In the middle of all this ancient culture, all these exquisite buildings, Li Bing's latest successor walks about, a slide-rule sticking out of his pocket, and with a Manchester training-Dr. Chang Yo-Ling. The British Scientific Mission has had particular pleasure in transmitting some of his papers for publication in British engineering journals.

It would be a delight also to speak of the chemists and engineers in the arsenals in this part of China, of their initiative and perseverance in erecting and operating up-to-date plants in the midst of the wilderness, and of the clever use that has been made of natural caverns for the protection of war science laboratories and special up-to-date machinery. But for security reasons this cannot be done. No one, however, could say, after seeing what the Chinese have done in technology, both ancient and modern, that they are a people inapt for the scientific control of Nature. If modern science did not develop in their country, it must have been due to specific inhibitory social and economic factors, and certainly not to any incapacity of the people themselves.

The tragic feature in to-day's situation is the economic straits of Chinese scientific men, especially in the universities. The steeply rising cost of living has hit them very hard, and neither the special rice allowances of the Government, nor the staving off of the evil day by the gradual selling of all the family possessions down to the children's dolls, avail to provide them with even a moderate standard of comfort and to guard against malnutrition. But this must be the subject of a later communication.

\section{FEEDING HORSE CHESTNUTS AND ELDERBERRIES TO POULTRY}

\section{By H. TEMPERTON \\ National Institute of Poultry Husbandry, Newport, Shropshire}

$\mathrm{T}$ HE commercial poultry keeper, faced with an acute shortage of concentrate feeding stuffs, has been compelled to exercise considerable ingenuity in finding suitable supplements to eke out his food allocation and so maintain a reasonable proportion of his pre-war numbers of stock. The same problem, although to a lesser degree, has confronted the domestic poultry keeper, who is allocated sufficient meal to furnish approximately half the daily food requirements of his birds. Thus a person qualifying for rations for only four birds requires an additional half-pound of dry food substance in order to provide a satisfactory daily ration for this number of stock. It is estimated ${ }^{I}$ that the daily amount of edible waste in the average small English household is approximately one pound of fresh substance, or approximately four ounces of dry matter. The further daily requirement of four ounces of palatable and nutritive dry matter must, therefore, be derived from other sources. The poultry Press, adopting the principle that no potential food source, however small in quantity relative to needs, should be despised, has frequently suggested the nutritive possibilities of natural food materials and requested youth movements and other voluntary services to collect acorns, horse chestnuts and beech mast for stock feed.

Reference to the available literature provides little experimental evidence of the value and effects of feeding such natural food materials to poultry, and it was considered desirable to obtain timely information. The use of acorns as a food for laying birds has already been described ${ }^{2}$, and the present article gives an account of experiences with the feeding of horse chestnuts and elderberries.

\section{Horse Chestnuts}

The chemical composition of horse chestnuts is very encouraging, the dry matter being similar to barley, as shown by the following analyses (Wood$\left.\operatorname{man}^{3}\right)$ :

\begin{tabular}{|c|c|c|c|c|c|c|}
\hline \multirow{2}{*}{$\begin{array}{lll} & & \\
& & \\
\text { Barley .. } & \text {.. }\end{array}$} & \multirow{2}{*}{$\begin{array}{c}\text { AveraGE } \\
\text { Dry } \\
\text { Matter }\end{array}$} & \multicolumn{3}{|c|}{ Composition Per Cent } & \multirow[b]{2}{*}{ Fibre } & \\
\hline & & $\begin{array}{c}\text { Protein } \\
10 \cdot 0\end{array}$ & $\underset{1.5}{\text { E.E. }}$ & $\begin{array}{l}\text { N.F.E. } \\
66 \cdot 5\end{array}$ & & \\
\hline Horse Chestnuts & 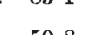 & s. & 20 & 00 & 8.5 & \\
\hline orse Chestnuts & $50 \cdot 8$ & $4 \cdot 3$ & $1 \cdot 5$ & $40 \cdot 9$ & $2 \cdot 5$ & \\
\hline (Dry) & $81 \cdot 2$ & $6 \cdot 9$ & $2 \cdot 4$ & $65 \cdot 2$ & $4 \cdot 1$ & \\
\hline
\end{tabular}

A characteristic constituent of the nitrogen-free extractives is a glycoside, esculin (æsculin, æsculinic acid) $\mathrm{C}_{18} \mathrm{H}_{18} \mathrm{O}_{3}$, which on hydrolysis yields esculetin (æsculetin, 6,7-dihydroxy-coumarin) $\mathrm{C}_{6} \mathrm{H}_{6} \mathrm{O}_{4}$ and glucose. Horse chestnuts also contain the glycoside quercitrin (quercinetrin, quercitrinie acid) $\mathrm{C}_{21} \mathrm{H}_{22} \mathrm{O}_{12}$. $2 \mathrm{H}_{2} \mathrm{O}$, which includes the $\omega$-desoxy sugar, $l$-rhamnose. On hydrolysis, quercitrin yields quercetin (meletin, sophoretin, quercitrinic acid, flavin) $\mathrm{C}_{15} \mathrm{H}_{10} \mathrm{O}_{7}$.

Esculin is a saponin and produces the characteristic soap-like foam which is apparent when cooked horse chestnuts are masticated. A sweet flavour remains which later turns to a bitter after-taste due to the presence of $l$-rhamnose and of gallotannin (gallotannic acid), a further constituent of horse chestnuts. Gallotannin is largely hydrolysed to gallic acid during the cooking of the nuts. Klimmer ${ }^{4}$ refers to deaths among poultry due to tannic acid poisoning following the feeding of horse chestnuts. It is unlikely, however, that this constituent was responsible, since in an experiment ${ }^{5}$ carried out with laying pullets the daily dosage of birds with $1.12 \mathrm{gm}$. of gallotannio acid over a period of twenty-five days did not adversely affect health or egg production although the birds were costive.

Outline of experiment. Four groups each comprising four cross-bred pullets which were in lay were used. 